\title{
PENGARUH PROFITABILITAS, STRUKTUR MODAL, KEBIJAKAN DEVIDEN, DAN KEPUTUSAN INVESTASI TERHADAP NILAI PERUSAHAAN \\ (Studi Kasus Perusahaan Manufaktur Yang Go Publik di Bursa Efek Indonesia) PERIODE 2010 - 2014
}

\author{
Sri Ayem* \\ Ragil Nugroho \\ Program Studi Akuntansi Fukultas Ekonomi \\ Universitas Sarjanawiyata Tamansiswa \\ *sriayemfeust@gmail.com
}

\begin{abstract}
This research aims to find empirical evidence about the influence of profitability on firm value. To find empirical evidence about the influence of capital structure on firm value. To find empirical evidence about the influence of dividend policy on firm value. To know more about the influence of empirical evidence Investment Decision on firm value. To know more about the influence of empirical evidence profitability, capital structure, dividend policy and investment decisions simultaneously on firm value.

Variables of this research are Profitability, Capital Structure, Dividend Policy, Investment Decisions and firm value. The type of data research is secondary data, it is manufacturing company's financial statements the period of 2010 - 2014. The analysis technique used is multiple linear regression with a significance level of $5 \%$.

The research results show that profitability have a positive and significant effect on firm value. Capital structure does not affect the firm value. Dividend policy is positive and significant effect on firm value. Investment policy and significant positive effect on firm value. Simultaneously profitability, capital structure, dividend policy and investment decisions are have significant effect on firm value. The effect of profitability, capital structure, dividend policy, and investment decisions to firm value by $37.5 \%$ while the rest influenced by other factors not included in the research model.
\end{abstract}

Keywords: Profitability, Capital Structure, Dividend Policy, Investment Decisions and Firm Value

\section{PENDAHULUAN}

Optimalisasi nilai perusahaan dapat dicapai melalui pelaksanaan fungsi manajemen keuangan, dimana satu keputusan keuangan yang diambil akan mempengaruhi keputusan keuangan lainnya dan berdampak pada nilai perusahaan. Menurut Suad dan Pudjiastuti, (2012), manajemen keuangan menyangkut penyelesaian atas keputusan penting yang diambil perusahaan, antara lain profitabilitas, struktur modal, keputusan deviden, dan keputusan investasi. Suatu kombinasi yang optimal atas keempat faktor tersebut akan memaksimumkan nilai perusahaan yang selanjutnya akan meningkatkan kemakmuran kekayaan pemegang saham. Investasi modal merupakan salah satu aspek utama dalam keputusan investasi selain penentuan komposisi aktiva. Keputusan pengalokasian modal ke dalam usulan investasi harus dievaluasi dan dihubungkan dengan risiko dan hasil yang diharapkan. Menurut signaling theory, pengeluaran investasi memberikan sinyal positif mengenai pertumbuhan perusahaan di masa yang akan datang, sehingga dapat meningkatkan harga saham yang digunakan sebagai indikator nilai perusahaan (Ningsih dan Indarti (2012). Keputusan yang menyangkut investasi akan 
menentukan sumber dan bentuk dana untuk pembiayaannya. Masalah yang harus dijawab dalam keputusan pendanaan yang dihubungkan dengan sumber dana adalah apakah sumber internal atau eksternal, besarnya hutang dan modal sendiri, dan bagaimana tipe hutang dan modal yang akan digunakan, mengingat struktur pembiayaan akan menentukan cost of capital yang akan menjadi dasar penentuan required return yang diinginkan.

Dalam berinvestasi para investor maupun calon investor perlu mengumpulkan informasi sebagai salah satu dasar pertimbangan dalam pengambilan keputusan investasi di pasar modal. Indikator yang biasanya digunakan para investor adalah dengan memperhatikan profitabilitasnya karena semakin tinggi laba, semakin tinggi pula return yang akan diperoleh investor. Pengambilan variabel ROE sebagai sampel dari indikator profitabilitas dikarenakan atas dasar ROE mempunyai keterkaitan yang paling kuat untuk dihubungkan dengan variabel Tobins'Q yang merupakan sebagai sampel dari indikator nilai perusahaan. Dimana ROE menunjukan berapa besarnya pengembalian atas modal atau equity yang akan dtanamkan oleh investor.

Tobin's $Q$ yaitu nilai pasar dari suatu perusahaan dengan membandingkan nilai pasar suatu perusahaan yang terdaftar di pasar keuangan dengan nilai penggantian aset (asset replacement value) perusahaan (Ningsih dan Indarti (2012). Penelitian ini mencoba meneliti nilai perusahaan dengan pendekatan harga saham dengan menggunakan rasio Tobin's Q. Alasan memilih rasio Tobin'q dalam penelitian ini untuk mengukur nilai perusahaan adalah karena penghitungan rasio Tobin's Q lebih rasional mengingat unsur-unsur kewajiban juga dimasukkan sebagai dasar penghitungan. Saat ini dunia usaha sangat tergantung pada masalah pendanaan. Struktur modal dalam penelitian ini diukur menggunakan DER (debt to equity ratio). Penelitian terdahulu masih menunjukkan ketidak pastian hubungan antara struktur modal terhadap nilai perusahaan. Menurut Rizqia, et al. (2013) struktur modal memiliki pengaruh positif terhadap nilai perusahaan.
Kemampuan perusahaan dalam membayarkan dividen dapat mencerminkan nilai perusahaan. Jika pembayaran dividen tinggi, maka harga saham juga tinggi yang berdampak pada tingginya nilai perusahaan begitu juga sebaliknya (Susanti, 2010). Dengan demikian, kebijakan dividen merupakan salah satu keputusan yang paling penting tentang kekhawatiran yang dihadapi oleh perusahaan dalam kebijakan dividen adalah seberapa banyak pendapatan yang bisa dibayarkan sebagai dividen dan seberapa banyak dapat dipertahankan. Dalam penelitian ini kebijakan dividen diukur dengan DPR (dividend payout ratio).

Kebijakan lain yang berkenaan dengan nilai perusahaan adalah keputusan investasi. Melakukan kegiatan investasi merupakan keputusan tersulit bagi manajemen perusahaan karena akan mempengaruhi nilai perusahaan. Tujuan dilakukannya keputusan investasi adalah mendapat laba yang besar dengan risiko yang dapat dikelola dengan harapan dapat mengoptimalkan nilai perusahaan (Afzal dan Abdul, 2012). Ni Luh Putu Rassri Gayatri dan I Ketut Mustanda. (2013) mendapat hasil penelitian bahwa keputusan investasi berpengaruh signifikan terhadap nilai perusahaan. Sedangkan Hamid (2012) berpendapat bahwa keputusan investasi tidak berpengaruh secara positif dan tidak signifikan terhadap nilai perusahaan. Perusahaan melakukan investasi bertujuan untuk mendapatkan keuntungan di masa yang akan datang. Keputusan investasi mempunyai jangka waktu yang panjang, sehingga keputusan yang diambil harus dipertimbangkan dengan baik, karena mempunyai risiko berjangka panjang pula. Kesalahan dalam mengadakan peramalan akan dapat mengakibatkan kerugian bagi perusahaan. Dalam penlitian ini proksi kebijakan investasi diukur dengan IOS.

\section{LANDASAN TEORI \\ Pengaruh profitabilitas terhadap nilai perusahaan \\ Profitabilitas adalah kemampuan perusahaan untuk memperoleh laba. Laba diperoleh perusahaan berasal dari penjualan dan}


investasi yang dilakukan perusahaan. Profitabilitas juga merupakan gambaran kinerja manajemen dalam mengelola perusahaan. Profitabilitas perusahaan dapat dihitung menggunakan ROE (return on Equity), dengan membagi laba bersih setelah pajak (earnings after tax) dengan modal sendiri.

Semakin tinggi ROE maka semakin tinggi kemampuan perusahaan untuk menghasilkan keuntungan dan akan membuat profitabilitas perusahaan tinggi. Profitabilitas yang tinggi akan memberikan sinyal positif bagi investor bahwa perusahaan berada dalam kondisi yang menguntungkan. Hal ini menjadi daya tarik investor untuk memiliki saham perusahaan. Permintaan saham yang tinggi akan membuat para investor menghargai nilai saham lebih besar dari pada nilai yang tercatat pada neraca perusahaan, sehingga nilai perusahaan pun tinggi. Dengan demikian maka profitabilitas memiliki pengaruh positif terhadap nilai perusahaan.

\section{Pengaruh Struktul Modal terhadap nilai perusahaan}

Struktur modal didefinisikan sebagai keputusan yang menyangkut komposisi pendanaan yang dipilih oleh perusahaan. Sumber pendanaan di dalam suatu perusahaan dibagi menjadi dua kategori yaitu pendanaan internal dan pendanaan eksternal. Setiap perusahaan akan mengharapkan adanya struktur modal optimal, yaitu struktur modal yang dapat memaksimalkan nilai perusahaan (value of the firm) dan meminimalkan biaya modal (cost of capital). Menurut pecking order theory, dana eksternal lebih disukai dalam bentuk hutang daripada modal sendiri karena dua alasan yaitu pertimbangan biaya emisi, dimana biaya emisi obligasi lebih murah dibandingkan biaya emisi saham baru. Hal ini disebabkan karena penerbitan saham baru akan menurunkan harga saham lama. Alasan kedua adalah adanya kekhawatiran manajer bahwa penerbitan saham baru dapat ditafsirkan sebagai kabar buruk oleh pemodal yang mengakibatkan menurunnya nilai perusahaan.

Manajer dapat menggunakan hutang sebagai sinyal yang lebih terpercaya untuk para investor. Ini karena perusahaan yang meningkatkan hutang dapat dipandang sebagai perusahaan yang yakin dengan prospek perusahaan di masa yang akan datang. Jadi penggunaan hutang merupakan tanda atau sinyal positif dari perusahaan yang dapat membuat para investor menghargai nilai saham lebih besar dari pada nilai yang tercatat pada neraca perusahaan, sehingga PBV perusahaan tinggi dan nilai perusahaan pun tinggi. meningkatkan nilai perusahaan. Dengan demikian maka keputusan pendanaan memiliki pengaruh positif terhadap nilai perusahaan.

\section{Pengaruh kebijakan dividen terhadap nilai perusahaan}

Pada dasarnya, laba bersih perusahaan dapat dibagikan kepada pemegang saham sebagai dividen atau ditahan dalam bentuk laba ditahan untuk membiayai investasi perusahaan. Kebijakan dividen berkaitan dengan kebijakan mengenai seberapa besar laba yang diperoleh perusahaan akan didistribusikan kepada pemegang saham (Titin Herawati (2013). Penelitian Wijaya dan Wibawa (2010), dapat membuktikan bahwa kebijakan dividen mempengaruhi nilai perusahaan secara positif. Menurut teori information content of dividend, investor akan melihat kenaikan dividen sebagai sinyal positif atas prospek perusahaan di masa depan. Pembagian dividen memberikan sinyal perubahan yang menguntungkan pada harapan manajer dan penurunan dividen menunjukkan pandangan pesimis prospek perusahaan dimasa yang akan datang.

Perusahaan yang dapat memberikan dividen tinggi juga akan mendapatkan nilai kepercayaan yang tinggi dari para investor, karena investor lebih menyukai kepastian tentang returns investasinya dan mengantisipasi risiko ketidakpastian tentang kebangkrutan perusahaan. Dividen yang tinggi akan membuat para investor tertarik sehingga meningkatkan permintaan saham. Permintaan saham yang tinggi akan membuat para investor menghargai nilai saham lebih besar dari pada nilai yang tercatat pada neraca perusahaan, sehingga PBV perusahaan tinggi dan nilai perusahaan pun tinggi. Dengan demikian maka kebijakan dividen memiliki pengaruh positif terhadap nilai perusahaan. 
Pengaruh keputusan investasi terhadap nilai perusahaan

Keputusan investasi adalah keputusan penanaman modal berjangka waktu lama yang menyangkut harapan terhadap hasil keuntungan yang diperoleh perusahaan di masa yang akan datang. Keputusan investasi mempunyai dimensi waktu jangka panjang, sehingga keputusan yang diambil harus dipertimbangkan dengan baik, karena mempunyai risiko berjangka panjang pula.

Signaling teory menjelaskan bahwa pengeluaran investasi memberikan sinyal positif tentang pertumbuhan perusahaan dimasa yang akan datang, sehingga meningkatkan harga saham sebagai indikator nilai perusahaan. Keputusan investasi dalam penelitian ini diproksikan dengan Price Earnings Ratio (PER). PER yang tinggi menunjukkan investasi perusahaan yang bagus dan prospek pertumbuhan perusahaan yang bagus sehingga para investor akan tertarik. Permintaan saham yang tinggi akan membuat para investor menghargai nilai saham lebih besar dari pada nilai yang tercatat pada neraca perusahaan, sehingga PBV perusahaan tinggi dan nilai perusahaan pun tinggi. Dengan demikian maka keputusan investasi memiliki pengaruh positif terhadap nilai perusahaan.

\section{METODOLOGI PENELITIAN}

Jenis penelitian yang digunakan adalah kuantitatif yaitu jenis penelitian yang berwujud angka-angka yang bersifat statistik (Sugiyono, 2006). Variabel penelitian ini adalah Profitabilitas, Struktur Modal, Kebijakan Deviden, Keputusan Investasi dan nilai perusahaan. Jenis Data penelitian adalah data sekuder berupa laporan keuangan perusahaan Manufaktur periode tahun 2010 - 2014. Teknik analisis yang digunakan adalah regresi linier berganda dengan taraf signifikansi $5 \%$.

\section{HASIL DAN PEMBAHASAN Gambaran Umum Obyek Penelitian}

Tabel 1

Prosedur Pemilihan Sampel

\begin{tabular}{clc}
\hline No. & \multicolumn{1}{c}{ Uraian } & Jumlah \\
\hline 1 & $\begin{array}{l}\text { Total perusahaan Manufaktur yang listing berturut-turut di BEI dari } \\
\text { tahun 2010 sampai 2014 }\end{array}$ & 65 \\
2 & $\begin{array}{l}\text { Perusahaan yang terkena delisting } \\
3\end{array}$ & $\begin{array}{c}\text { Perusahaan yang tidak mengeluarkan laporan keuangan secara } \\
\text { lengkap dari 2010 - 2014 }\end{array}$ \\
$\quad \begin{array}{l}\text { Total sampel Perusahaan } \\
\text { Total observasi selama 2010 - 2014 }\end{array}$ & 22 \\
\hline
\end{tabular}

Sumber : http://www.sahamok.com

Tabel 1. menunjukkan terdapat 31 sampel perusahaan manufaktur yang memenuhi kriteria dari 65 perusahaan manufaktur yang listing di BEI selama 2010 sampai 2014, 12 perusahaan manufaktur terkena delisting dan 22 perusahaan tidak melaporkan keuangan secara lengkap dari tahun 2010 sampai 2014. 


\section{Statistik Diskriptif Variabel}

Tabel 2.

Descriptive Statistics Variabel

\begin{tabular}{llrrrr}
\hline & N & Minimum & Maximum & \multicolumn{1}{c}{ Mean } & Std. Deviation \\
\hline Nilai Perusahaan & 155 &, 108 & 11,868 & 2,63633 & 2,006867 \\
Profitabilitas & 155 &, 010 & 3,457 &, 27851 &, 418488 \\
Struktur Modal & 155 &, 004 & 9,040 & 1,39990 & 1,571632 \\
Kebijakan Deviden & 155 &, 002 & 2,304 &, 57165 &, 311379 \\
Kebijakan Investasi & 155 &, 030 & 12,864 & 2,39991 & 2,618940 \\
Valid N (listwise) & 155 & & & & \\
\hline
\end{tabular}

Tabel 2. menunjukkan bahwa variabel nilai perusahaan $(\mathrm{Y})$ memiliki nilai minimum sebesar 0,108 dan nilai maksimum sebesar 11,868, nilai rata-rata sebesar 2,63633dengan standar deviasi 2,006867, Profitabilitas $\left(\mathrm{X}_{1}\right)$ memiliki nilai minimum sebesar 0,010 dan nilai maksimum sebesar 3,457 nilai rata-rata sebesar 0,27851 dengan standar deviasi 0, 418488 . Variabel struktur modal $\left(\mathrm{X}_{2}\right)$ memiliki nilai minimum sebesar 0,004 dan nilai maksimum sebesar 9,040, nilai rata-rata sebesar 1,39990 dengan standar deviasi 1,571632. Variabel kebijakan deviden $\left(\mathrm{X}_{3}\right)$ memiliki nilai minimum sebesar 0,002 dan nilai maksimum sebesar 2,304, nilai rata-rata sebesar 0,57165 dengan standar deviasi 0,311379. Variabel kebijakan investasi $\left(\mathrm{X}_{3}\right)$ memiliki nilai minimum sebesar 0,030 dan nilai maksimum sebesar 12,864 , nilai rata-rata sebesar 2,39991 dengan standar deviasi 2,618940 .

\section{Uji Asumsi Klasik}

Uji Normalitas

Tabel 3.

Uji Normalitas

\begin{tabular}{llr}
\hline & & \multicolumn{2}{c}{ Unstandardized Residual } \\
\hline Normal Parameters ${ }^{\mathrm{a}, \mathrm{b}}$ & Mean & 155 \\
& Std. Deviation &, 0000000 \\
& Absolute & 1,38811370 \\
Most Extreme Differences & Positive &, 094 \\
& Negative &, 094 \\
Kolmogorov-Smirnov Z & &,- 034 \\
Asymp. Sig. (2-tailed) & & 1,175 \\
& &, 127 \\
\hline
\end{tabular}

Tabel 3. menunjukkan bahwa nilai Kolmogrov-Smirnov $Z$ sebesar 1,175 dan nilai Asymp. Sig. (2-tailed) sebesar $0,127(0,127>0,05)$ yang diperoleh model regresi lebih dari $\alpha(\mathrm{p}>0,05)$, berarti berdistribusi normal. 


\section{Uji Multikolinieritas}

Tabel 4

Hasil Uji Multikolinieritas

\begin{tabular}{|c|c|c|c|}
\hline \multirow{2}{*}{\multicolumn{2}{|c|}{ Model }} & \multicolumn{2}{|c|}{ Collinearity Statistics } \\
\hline & & Tolerance & VIF \\
\hline \multirow[t]{5}{*}{1} & (Constant) & & \\
\hline & Profitabilitas & ,935 & 1,070 \\
\hline & Struktur Modal & ,977 & 1,024 \\
\hline & Kebijakan Deviden & ,890 & 1,123 \\
\hline & $\begin{array}{l}\text { Kebijakan } \\
\text { Investasi }\end{array}$ & ,902 & 1,109 \\
\hline
\end{tabular}

Berdasarkan tabel 4. menunjukkan bahwa nilai tolerance untuk variabel profitabilitas sebesar 0,935 dengan nilai VIF 1,070, struktur modal sebesar 0,977 dengan nilai VIF 1,024. Kebijakan deviden sebesar 0,890 dengan nilai VIF 1,123. Kebijakan investasi sebesar 0,902 dengan nilai VIF 1,109. Hasil diatas semua variabel bebas memiliki nilai VIF lebih kecil dari 10, sehingga dapat disimpulkan bahwa tidak ada multikolinieritas.

\section{Uji Autokolerasi}

\section{Tabel.5.}

Hasil Uji Autokolerasi

\begin{tabular}{cc}
\hline Nilai Durbin-Watson & Keterangan \\
\hline 1,711 & $\begin{array}{c}\text { Tidak ada } \\
\text { Autokolerasi }\end{array}$ \\
\hline
\end{tabular}

dari hasil output SPSS diatas dapat diketahui nilai DW sebesar dl $(1,6188 \leq 1,711 \leq$ 4-du (2,2934), hal ini menunjukkan bahwa regresi tidak ada autokorelasi.

\section{Uji Heterokedastisitas}

Tabel 6

Hasil Uji Heterokedastisitas

\begin{tabular}{llrr}
\hline \multicolumn{1}{c}{ Model } & \multicolumn{1}{c}{ t } & Sig. \\
\hline 1 & (Constant) & 3,309 &, 001 \\
& Profitabilitas & 1,237 &, 219 \\
& Struktur Modal &, 391 &, 697 \\
& Kebijakan Deviden & 1,768 &, 080 \\
& Kebijakan Investasi &,- 236 &, 814 \\
& & & \\
\hline
\end{tabular}

Uji heterokedastisitas menggunakan uji Glejser. Tabel 4.6. menunjukkan bahwa nilai signifikan semua variabel bebas lebih besar dari 0,05 ( $p>0,05)$, maka tidak signifikan, sehingga dapat disimpukan tidak terjadi heteroskedastisitas.

\section{Analisis Data}

\section{Regresi Linier Berganda}

Tabel 7

Hasil Regresi Linier Berganda

\begin{tabular}{|c|c|c|c|c|c|c|}
\hline & \multirow[t]{2}{*}{ Model } & \multicolumn{2}{|c|}{$\begin{array}{l}\text { Unstandardized } \\
\text { Coefficients }\end{array}$} & $\begin{array}{l}\text { Standardized } \\
\text { Coefficients }\end{array}$ & \multirow[t]{2}{*}{$t$} & \multirow[t]{2}{*}{ Sig. } \\
\hline & & $\mathrm{B}$ & Std. Error & Beta & & \\
\hline \multirow[t]{5}{*}{1} & (Constant) &,- 008 & ,278 & &,- 029 & ,977 \\
\hline & Profitabilitas & 1,265 & ,280 & 264 & 4,516 & ,000 \\
\hline & Struktur Modal & , 104 & 073 & ,082 & 1,429 & 155 \\
\hline & Kebijakan Deviden & 2,230 & ,386 & ,346 & 5,782 & ,000 \\
\hline & Kebijakan Investasi & ,385 & 054 & 425 & 7,150 &, 000 \\
\hline
\end{tabular}

Persamaan regresi :

$$
Y=-0,008+1,265 X_{1}+0,104 X_{2}+2,230 X_{3}+0,385 X_{4}
$$

$\square 1=1,265$ artinya apabila variabel lain dianggap konstan maka setiap kenaikan profitabilitas sebesar $1 \%$, maka akan menaikkan nilai perusahaan sebesar 1,265\%. $\square 2=0,104$ artinya apabila variabel lain dianggap konstan maka setiap kenaikan struktur modal sebesar $1 \%$, maka akan menaikan nilai perusahaan 
sebesar $0,104 \% . \square 3=2,230$ artinya apabila variabel lain dianggap konstan maka setiap kenaikan kebijkan deviden sebesar 1\%, maka akan menaikan nilai perusahaan sebesar $2,230 \%$. $\square \square 4=0,385$ artinya apabila variabel lain dianggap konstan maka setiap kenaikan kebijakan investasi sebesar $1 \%$, maka akan menaikan nilai perusahaan sebesar $0,385 \%$.

\section{Uji t}

\section{Profitabilitas}

p-value profitabilitas sebesar $0,000<$ $0,05(p<0,05)$, sehingga Ha diterima Ho ditolak atau $\mathrm{H} 1$ diterima, yang artinya profitabilitas berpengaruh signifikan terhadap nilai perusahaan. Pengaruh profitabilitas terhadap nilai perusahaan bersifat positif artinya semakin besar profitabilitas maka semakin tinggi nilai perusahaan. Profitabilitas yang tinggi akan memberikan sinyal positif bagi investor bahwa perusahaan berada dalam kondisi yang menguntungkan atau memiliki kemampuan laba, dalam hal ini adalah kemampuan perusahaan dalam menghasilkan laba atas modal sendiri. Hal ini menjadi daya tarik investor untuk memiliki saham perusahaan tersebut, sehingga permintaan saham yang tinggi akan meningkatkan nilai jual perusahan menjadi semakin besar atau nilai perusahaan mengalami peningkatan.

\section{Struktur Modal}

p-value struktur modal sebesar 0,192 > $0,05$ ( $p>0,05)$, sehingga Ha ditolak Ho diterima atau $\mathrm{H} 2$ ditolak, yang artinya struktur modal tidak berpengaruh terhadap nilai perusahaan. Pengaruh struktur modal terhadap nilai perusahaan bersifat positif artinya semakin besar struktur modal maka semakin tinggi nilai perusahaan. Hal ini menunjukkan perusahaan lebih menyukai modal sendiri dalam berinvestasi dibanding dengan hutang, dengan menerbitkan saham-saham baru, yang diyakini manajemen lebih efisien.

\section{Kebijakan Deviden}

p-value kebijakan deviden sebesar 0,000 $<0,05(\mathrm{p}<0,05)$, sehingga Ha diterima Ho ditolak atau $\mathrm{H} 3$ diterima, yang artinya kebijakan deviden berpengaruh signifikan terhadap nilai perusahaan. Pengaruh kebijakan deviden terhadap nilai perusahaan bersifat positif artinya semakin besar kebijakan deviden maka semakin tinggi nilai perusahaan. Kebijakan dividen berkaitan dengan kebijakan mengenai seberapa besar laba yang diperoleh perusahaan akan didistribusikan kepada pemegang saham. Semakin besar laba yang dibagikan kepada pemegang saham, maka ketertarikan investor dalam perusahaan tersebut semakin besar, sehingga meningkatkan nilai perusahaan.

\section{Kebijakan Investasi}

p-value kebijakan investasi sebesar 0,005 $<0,05(\mathrm{p}<0,05)$, sehingga Ha diterima Ho ditolak atau $\mathrm{H} 4$ diterima, yang artinya kebijakan investasi berpengaruh signifikan terhadap nilai perusahaan. Pengaruh kebijakan investasi terhadap nilai perusahaan bersifat positif artinya semakin besar kebijakan investasi maka semakin tinggi nilai perusahaan. Pengeluaran investasi memberikan sinyal positif tentang pertumbuhan perusahaan dimasa yang akan datang, sehingga meningkatkan harga saham sebagai indikator nilai perusahaan. Semakin besar investasi yang ditanamkan perusahaan, maka akan semakin tinggi keuntunggan atau laba didapat perusahaan, hal ini akan mendorong tingginya investor menanmkan modalnya diperusahaan tersebut, sehingga akan meningkatkan nilai perusahaan. 


\section{Uji F}

Tabel 8

\begin{tabular}{|c|c|c|c|c|c|c|}
\hline \multirow{2}{*}{\multicolumn{2}{|c|}{ Model }} & \multicolumn{4}{|c|}{ Hasil Uji F } & \multirow{2}{*}{ Sig. } \\
\hline & & Sum of & & Mean & & \\
\hline \multirow[t]{3}{*}{$\overline{1}$} & Regression & 323,501 & 4 & 80,875 & 40,882 &, $000^{\mathrm{a}}$ \\
\hline & Residual & 296,736 & 150 & 1,978 & & \\
\hline & Total & 620,237 & 154 & & & \\
\hline
\end{tabular}

Dari tabel diatas dapat dilihat bahwa variabel independen yaitu profitabilitas, struktur modal, kebijakan deviden, dan kebijakan investasi, secara serentak dan signifikan berpengaruh terhadap nilai perusahaan yang ditunjukkan oleh signifikansi sebesar 0,000 lebih kecil dari probabilitas kesalahan yaitu 0,05, sehingga $\mathrm{H} 5$ diterima.

\section{Koefisien Determinasi}

\begin{tabular}{|c|c|c|c|c|}
\hline & Has & $\begin{array}{r}\text { Tabe } \\
\text { I Adjuste } \\
\end{array}$ & R Square & \\
\hline Model & $\mathrm{R}$ & R Square & $\begin{array}{l}\text { Adjusted R } \\
\text { Square }\end{array}$ & $\begin{array}{c}\text { Std. Error of the } \\
\text { Estimate }\end{array}$ \\
\hline-1 &, $722^{a}$ & ,522 &, 509 & 1,406500 \\
\hline
\end{tabular}

Dari hasil analisis regresi yang dilakukan diperoleh adjusted $\mathrm{R}$ Square sebesar 0,509 atau $50,9 \%$ yang artinya bahwa pengaruh variabel independen yaitu profitabilitas, struktur modal, kebijakan deviden, dan kebijakan investasi terhadap nilai perusahaan sebesar $50,9 \%$ sedangkan sisanya dipengaruhi oleh faktor lain yang tidak masuk dalam model penelitian.

\section{HASIL DAN PEMBAHSAN}

Profitabilitas berpengaruh positif dan signifikan terhadap nilai perusahaan. Hal ini menunjukkan bahwa semakin besar profitabilitas suatu perusahaan, maka akan semakin besar nilai perusahaan. Hal ini sesuai pendapat Husnan (2013), yang menyatakan semakin tinggi ROE maka semakin tinggi kemampuan perusahaan untuk menghasilkan keuntungan dan akan membuat profitabilitas perusahaan tinggi. Profitabilitas yang tinggi akan memberikan sinyal positif bagi investor bahwa perusahaan berada dalam kondisi yang menguntungkan. Hal ini menjadi daya tarik investor untuk memiliki saham perusahaan. Permintaan saham yang tinggi akan membuat para investor menghargai nilai saham lebih besar dari pada nilai yang tercatat pada neraca perusahaan, sehingga nilai Tobins' $Q$ perusahaan tinggi dan nilai perusahaan pun tinggi. Hal ini dukung peneliti Nani Martikarini (2013), yang menyatakan bahwa profitabilitas yang diukur dengan ROE, berpengaruh terhadap nilai perusahaan. Semakin besar rasio ROE, maka semakin tinggi nilai perusahaan.

Struktur modal tidak berpengaruh terhadap nilai perusahaan. Hal ini menunjukkan bahwa perusahaan sampel sebagain besar memiliki modal yang kuat, sehingga besarnya hutang tidak berpengaruh terhadap nilai perusahaan. Hal ini menunjukkan perusahaan lebih menyukai modal sendiri dalam berinvestasi dibanding dengan hutang, dengan 
menerbitkan saham-saham baru, yang diyakini manajemen lebih efisien. Hal ini dukung peneliti Titin Herawati (2013), yang menyatakan bahwa Kebijakan hutang yang diukur dengan rasio DER berpengaruh tidak signifikan dan positif terhadap nilai perusahaan.

Kebijakan deviden berpengaruh positif dan signifikan terhadap nilai perusahaan. Hal ini menunjukkan bahwa semakin besar deviden yang diterima pemegang saham, maka akan semakin besar nilai perusahaan. Hal ini sesuai pendapat Sofyaningsih dan Hardiningsih, (2011) yang menyatakan pada dasarnya, laba bersih perusahaan dapat dibagikan kepada pemegang saham sebagai dividen atau ditahan dalam bentuk laba ditahan untuk membiayai investasi perusahaan. Kebijakan dividen berkaitan dengan kebijakan mengenai seberapa besar laba yang diperoleh perusahaan akan didistribusikan kepada pemegang saham. Hal ini dukung peneliti Wijaya dan Wibawa (2010), dapat membuktikan bahwa kebijakan dividen mempengaruhi nilai perusahaan secara positif. Menurut teori information content of dividend, investor akan melihat kenaikan dividen sebagai sinyal positif atas prospek perusahaan di masa depan. Pembagian dividen memberikan sinyal perubahan yang menguntungkan pada harapan manajer dan penurunan dividen menunjukkan pandangan pesimis prospek perusahaan dimasa yang akan datang.

Kebijakan investasi berpengaruh positif dan signifikan terhadap nilai perusahaan. Hal ini menunjukkan bahwa semakin besar dana yang dinvestasikan, maka akan semakin besar nilai perusahaan. Hal ini sesuai pendapat Sartono, (2001) yang menyatakan pengeluaran investasi memberikan sinyal positif tentang pertumbuhan perusahaan dimasa yang akan datang, sehingga meningkatkan harga saham sebagai indikator nilai perusahaan. Hal ini didukung peneliti terdahulua Ni Luh Putu Rassri Gayatri dan I Ketut Mustanda (2013), yang menyatakan keputusan investasi berpengaruh positif dan signifikan terhadap nilai perusahaan.

\section{KESIMPULAN}

Berdasarkan hasil penelitian yang dilakukan, maka kesimpulan dalam penelitian ini adalah:

1. Profitabilitas berpengaruh positif dan signifikan terhadap nilai perusahaan. Hal ini menunjukkan bahwa semakin besar profitabilitas suatu perusahaan, maka akan semakin besar nilai perusahaan.

2. Struktur modal tidak berpengaruh terhadap nilai perusahaan. Hal ini menunjukkan bahwa perusahaan sampel sebagain besar memilki modal yang kuat, sehingga besarnya hutang tidak berpengaruh terhadap nilai perusahaan.

3. Kebijakan deviden berpengaruh positif dan signifikan terhadap nilai perusahaan. Hal ini menunjukkan bahwa semakin besar deviden yang diterima pemegang saham, maka akan semakin besar nilai perusahaan.

4. Kebijakan investasi berpengaruh positif dan signifikan terhadap nilai perusahaan. Hal ini menunjukkan bahwa semakin besar dana yang dinvestasikan, maka akan semakin besar nilai perusahaan

5. Secara serentak profitabilitas, struktur modal, kebijakan deviden dan kebjakan investasi berpengaruh signifikan terhadap nilai perusahaan.

6. Pengaruh profitabilitas, struktur modal, kebijakan deviden, dan kebijakan investasi terhadap nilai perusahaan sebesar $37,5 \%$ sedangkan sisanya dipengaruhi oleh faktor lain yang tidak masuk dalam model penelitian.

\section{DAFTAR PUSTAKA}

Afzal, Arie dan Abdul Rohman. (2012). "Pengaruh Keputusan Investasi, Keputusan Pendanaan, dan Kebijakan Dividen terhadap Nilai Perusahaan". Journal of Accounting, 1(2): h:9

Ghozali, Imam. (2011). Aplikasi Analisis Multivariate Dengan Program SPSS. Badan Penerbit Universitas Diponegoro. Semarang.

Hamid. (2012). "Pengaruh Keputusan Investasi, Keputusan Pendanaan, Kebijakan Deviden, Struktur Kepemilikan Dan 